\title{
Carrier et la Révolution française en 30 questions
}

\section{Raymonde Monnier}

\section{(2) OpenEdition}

\section{Journals}

\section{Édition électronique}

URL : https://journals.openedition.org/ahrf/2020

DOI : 10.4000/ahrf.2020

ISSN : 1952-403X

Éditeur :

Armand Colin, Société des études robespierristes

Édition imprimée

Date de publication : 1 juin 2005

Pagination : 188

ISSN : 0003-4436

\section{Référence électronique}

Raymonde Monnier, "Carrier et la Révolution française en 30 questions ». Annales historiques de la Révolution française [En ligne], 340 | avril-juin 2005, mis en ligne le 20 avril 2006, consulté le 22 avril 2022. URL : http://journals.openedition.org/ahrf/2020 ; DOI : https://doi.org/10.4000/ahrf.2020

Ce document a été généré automatiquement le 22 avril 2022.

Tous droits réservés 


\title{
Carrier et la Révolution française en 30 questions
}

\author{
Raymonde Monnier
}

\section{RÉFÉRENCE}

Corinne GOMEZ-LE CHEVANTON, Carrier et la Révolution française en 30 questions, La

Crèche, Geste éditions, 2004, 64 p. (coll. dirigée par Jean-Clément Martin), ISBN

2-84561-155-2, 9 e.

1 Ce petit livre aborde de manière précise les questions essentielles qui peuvent se poser sur le représentant Carrier, sa mission à Nantes d'octobre 1793 à février 1794 dans le contexte de la guerre de Vendée, et les procès qui suivirent la chute de Robespierre. B. Baczko a montré comment l'écho des procès en chaîne du "moment thermidorien ", qui se déroulent en plein débat sur les responsabilités de la Terreur et aboutissent à la condamnation de Carrier, ont contribué à faire de la répression à Nantes une formidable caisse de résonance et le symbole des horreurs de la Terreur en province. La profusion d'écrits, de représentations et de caricatures liés au procès ont construit sur le moment la légende noire de Jean-Baptiste Carrier, sur fond de noyades dans la Loire et de "mariages républicains ", faisant de lui un des personnages les plus exécrables de la Révolution, et l'archétype de tous les excès de la Terreur. Comment les logiques révolutionnaires mises en œuvre à Paris et en Vendée pour faire face à la guerre, puis pour sortir de la Terreur, ont masqué les véritables questions, celles de l'attitude de l'ensemble de la classe politique révolutionnaire et de la responsabilité personnelle de Carrier, celle de ses rapports avec les pouvoirs locaux, enfin celle des enjeux de la mémoire ? La réponse à ces questions, notamment celle de la responsabilité personnelle de Carrier, renvoie au contexte national et à la situation exceptionnelle de la ville de Nantes dans la guerre civile, à la résistance vendéenne et aux luttes révolutionnaires régionales. Quels furent les rapports de Carrier avec les autorités locales? Quelle fut l'attitude de la population face aux mesures révolutionnaires? Quelle fut l'étendue de la répression? le rôle des autres acteurs terroristes? La dimension exceptionnelle prise 
par la figure de Carrier et la Terreur à Nantes dans l'histoire de la Révolution est liée à l'écho des procès de 1794 et aux enjeux de la mise en accusation de Carrier. Quand il est le seul à légitimer la violence révolutionnaire, d'autres grands terroristes se refont une virginité politique dans la période trouble de Thermidor ; l'affaire Carrier vient à point construire un contre-imaginaire intense pour faire oublier la tension héroïque de l'an II et clore la Révolution. L'intérêt du livre est d'aborder aussi la place de la Terreur nantaise dans la mémoire de la guerre de Vendée et dans la mémoire blanche qui a construit l'unité de la région sur une forte tradition d'inspiration contrerévolutionnaire. 